JIIP: JURNAL ILMIAH ILMU PEMERINTAHAN

Vol.6, No. 1, 2021

DOI: $10.14710 /$ jiip.v6i1.8618

\title{
Quo Vadis Parliamentary Threshold di Indonesia
}

\author{
Aenal Fuad Adam ${ }^{1}$, Wellem Levi Betaubun², Nur Jalal ${ }^{3}$ \\ 1,2,3 Jurusan Ilmu Administrasi Negara, Universitas Musamus Merauke
}

Dikirimkan: 5 Agustus 2020 Direvisi: 7 Februari $2021 \quad$ Diterbitkan: 25 Maret 2021

\begin{abstract}
INTISARI
Parliamentary Treshold sebagai syarat memperkuat sistem presidensial menjadi tajuk diskursus publik maupun ilmiah sejak penerapan sistem multipartai di Indonesia. Ada dugaan yang menjelaskan bahwa untuk membantu berjalannya sistem politik agar stabil maka diperlukan menyederhanakan jumlah partai politik melalui penerapan parliamentary threshold agar pemerintahan berjalan lebih efektif. Namun, apakah partai politik tidak akan bertumbuh, apakah jumlah partai politik akan berkurang, dan lantas apakah hipotesis ini benar? Tujuan tulisan ini menganalisis isu naiknya angka parliamentary threshold yang diguangkan oleh elitelit parpol di parlemen demi penyederhanaan sistem kepartaian untuk mewujudkan pemerintahan yang efektif. Artikel ini menggunakan metode penelitian kualitatif dengan memakai pendekatan historis institusionalisme sebagai pisau analisisnya. Studi pustaka menjadi model memperoleh data dan dianalisis kemudian disimpulkan. Artikel ini berpendapat parliamentary treshold tidak memberikan kondisi yang cukup untuk menyederhanakan sistem kepartaian di parlemen. Pada praktiknya, sistem multipartai adalah sebuah keniscayaan yang harus diterima dalam dinamika partai politik di Indonesia. Begitu juga tumbuh kembangnya partai politik berjalan seiring dengan perkembangan pemilu dan demokrasi di Indonesia.
\end{abstract}

\section{KATA KUNCI}

parliamentary treshold; penyederhanaan partai politik; sistem kepartaian; mutipartai

\section{Pendahuluan}

Sejak pasca reformasi politik di Indonesia, Undang - Undang Pemilu legislatif kerapkali mengalami pengubahan reglemen terhadap tata kelola pemilu. Salah satu yang acap kali berubah adalah parliamentary threshold atau ambang batas parlemen yaitu aturan batas minimal partai politik untuk menempatkan calon legislatif di parlemen. Akhir - akhir ini pun kembali mengalami perubahan dimana Komisi II DPR akan melakukan revisi UU Nomor 7 Tahun 2017 tentang Pemilihan Umum menyangkut parliamentary treshold atau ambang batas parlemen kini menjadi perdebatan besar antara elite - elite parpol, akademisi maupun pegiat pemilu dan demokrasi saat ini. Persoalan utama ambang batas parlemen adalah syarat besaran angka parliamentary treshold atau PT di pemilu tahun 2024 akan datang diwacanakan kembali digodok

Korespodensi:

Jurusan Ilmu Administrasi Negara, Fakultas Ilmu Sosial dan Ilmu Politik, Jl. Kamizaun Mopah Lama, Rimba Jaya, Kabupaten Merauke, Papua 99611

Email: adam@unmus.ac.id 
dimana memiliki tiga alternatif, pertama PT 4\% diusulkan PKS, PAN, PPP dan Demokrat, kedua PT 5\% diusulkan PDIP, ketiga PT 7\% diusulkan Nasdem dan Golkar (Simanjuntak, 2020). Tentu saja logika penentuan besaran angka ambang batas parlemen merupakan cara berfikir parpol yang dilandasi tujuan menyederhanakan partai politik di parlemen demi memperkuat sistem pemerintahan presidensil di Indonesia.

Dalam literatur pemilu, penerapan parliamentary treshold dimaknai sebagai syarat minimal suara yang harus dimiliki partai politik untuk menempatkan anggotanya menuju kursi di parlemen (Marijan, 2011; Prihatmoko, 2005; Yuda, 2010). Konsep ini dianggap sebagai instrumen untuk mengurangi bertumbuhnya partai politik baru dan dilain sisi memperketat jarak ideologis antar partai politik agar artikulasi dan agregasi kepentingan lebih efektif (Prihatmoko, 2008). Secara teori, pengaturan parliamentary threshold begitu berpengaruh terhadap penataan sistem kepartaian apakah akan membentuk sistem dwi partai atau multipartai sebagai produk pemilu (Reynolds \& Mellaz, 2011). Signifikansi dari perubahan aturan parliamentary treshold diindikasi dapat mengurangi jumlah partai politik di parlemen yang pada gilirannya berimplikasi terhadap penyederhanaan partai politik di parlemen. Namun kecenderungan seperti ini dipercaya akan merumitkan pertumbuhan partai politik baru di parlemen Indonesia.

Apabila kita melihat penerapannya, parliamentary threshold pertamakali berlaku pada pemilu 2009 dengan ambang batas parlemen 2,5\%, pemilu 2014 ambang batas parlemen 3,5\% dan pemilu 2019 naik menjadi 4\%. Dengan naiknya syarat parliamentary threshold dipandang bisa menyederhanakan sistem multipartai di Indonesia dengan semangat untuk membentuk sistem "multipartai sederhana" agar terbentuknya pemerintahan yang efektif dan stabil (Partono, 2008). Meskipun istilah "multipartai sederhana" menurut artikel ini sebetulnya abu - abu dan tidak memiliki indikator yang cukup jelas kapan sebuah Negara dianggap berada pada situasi dan dalam kondisi memiliki sistem multipartai sederhana. Hal ini menjadi paradoks yang kerapkali menghantui cara pandang parpol di parlemen. Selain itu, jumlah partai yang banyak di parlemen diyakini berpengaruh terhadap keefektifan pengambilan kebijakan yang berdampak pada kinerja pemerintah. Asumsinya adalah semakin banyak partai politik di parlemen semakin rendah keefektifan pengambilan kebijakan sehingga memperburuk kapasitas pemerintahan.

Apakah dengan menaikkan parliamentary treshold dapat menyederhanakan sistem kepartaian di Indonesia? Dapat dikatakan, penyederhanaan sistem kepartaian melalui kebijakan parliamentary threshold atau ambang batas perolehan suara partai politik di parlemen kerapkali menjadi produk kebijakan politik - hukum yang mengikat peserta pemilu. Hal ini seringkali terlihat dimana parpol di parlemen berupaya mengutak-atik Undang - Undang pemilu setiap 5 tahun sekalinya menjelang kontestasi pemilu di Indonesia. Bila berkaca dari sejarahnya, pemberlakuan parliamentary threshold bermula dari penerapan UU No 10 tahun 2008 pasal 202 tentang ambang batas parlemen sebagai syarat penentuan perolehan kursi partai politik di parlemen di 
pemilu tahun 2009 yang hingga kini menjadi trend politik. Hingga demikian, parliamentary threshold dipandang sebagai produk repetisi politis yang acap kali menjadi game theory - ruang negoisasi antar partai politik di parlemen. Rekayasa kebijakan elektoral inipun dipandang sebagai kepentingan politik yang bermuara pada kalkulasi serta tarik menarik kepentingan antar parpol yang menyampingkan kedaulatan rakyat (Aminah, Zia, Afita, \& Sitorus, 2020; Hadi \& Brata, 2020; Wardhono, Indrawati, \& Qoriah, 2012). Logika semacam ini pada dipandang sebagai kepentingan jangka pendek partai politik di parlemen. Hal ini terlihat dari sikap politik politik yang berimplikasi terjadinya tarik - menarik kepentingan penentuan angka parliamentary threshold di parlemen (Zuhri, 2018). Pada gilirannya perbedaan persepsi revisi UU Pemilu 2024 menyoal nilai ambang batas yang disodorkan disetiap fraksi di Parlemen menjadi arena negoisasi kepentingan politik parpol di parlemen (CNN Indonesia, 2020). Sementara di sisi lain, wacana revisi UU pemilu 2024 menjadi ancaman bagi partai politik baru maupun non parlemen yang dipandang dapat menghambat masuknya partai politik kecil untuk masuk ke kursi parlemen di pemilu akan datang (www.cnnindonesia.com, 2020).

Melihat realitas diatas, artikel ini berupaya mengangkat permasalahan mengenai kebijakan parliamentary threshold pada konteks pemilu tahun 2024 di Indonesia akan datang. Tulisan ini akan berupaya menjelaskan bahwa revisi UU pemilu 2024 dengan menaikkan jumlah parliemantay threshold atau ambang batas perolehan kursi parpol di parlemen bukan menjadi jaminan akan terciptanya sistem multipartai sederhana pada pemilu legislatif di tahun 2024. Oleh karena itu penulis menggunakan pendekatan studi literatur untuk menjelaskan dinamika parliamentary threshold. Untuk metode penelitian, penulis menggunakan metode kualitatif dengan jenis penelitian studi literatur. Sedangkan jenis data yang digunakan bersumber dari riset pustaka, dokumen, artikel media cetak maupun online (Zed, 2014). Data ini kemudian dianalisa menggunakan teknik analisis deskriptif.

\section{Sejarah Kemunculan Partai Politik di Indonesia}

Sudah menjadi keniscayaan bahwa tidak ada demokrasi tanpa partai politik (No, Parties, No Democracy). Partai politik dibutuhkan agar demokrasi bisa berfungsi. Paling tidak ada tiga alasan mengapa partai politik diperlukan agar demokrasi dapat berfungsi. Pertama, partai politik adalah saluran utama representasi politik. Kedua, partai politik merupakan prosedur utama pengelolaan pemerintahan. Ketiga, partai politik sebagai media untuk menegakkan akuntabilitas demokrasi (NIMD, 2006). Susan Scarrow menyebutkan bahwa sejarah munculnya partai - partai politik di suat negara dengan negara yang lain memang tidak selalu persis. Namun, ada faktor yang menghubungkannya yaitu kehadiran partai politik memiliki hubungan proporsionalitas dengan proses kemajuan demokratisasi (Marijan, 2011). Apa yang dikatakan Scarrow bahwa semakin meluasnya hak - hak masyarakat di untuk berkumpul dan berserikat serta berpendapat di sebuah Negara. Dalam sejarah kepartaian di Indonesia, 
kemunculan partai - partai politik tidak bisa dilepaskan dari kebijakan kolonial belanda yang menerapkan politik etis. Implikasinya adalah saling berkait-kelindan dengan pertumbuhan pembangunan politik, tetapi menguaknya iklim kebebasan berserikat yang didapatkan oleh seluruh warga Negara (Marijan, 2011). Selain itu, munculnya partai politik di Indonesia berkaitan dengan tumbuhnya gerakan sosial, yang tidak saja dimaksudkan untuk memperoleh kebebasan yang luas dari pemerintahan kolonial Belanda, melainkan pada akhirnya menuntut kemerdekaan. Diantara partai - partai yang muncul sebelum kemerdekaan adalah Partai Sarikat Islam Indonesia (PSII), Indische Partij, ISDV (cikal bakal PKI) dan PNI (Marijan, 2011). Disini sudah mulai nampak bahwa kemunculan banyak partai di Indonesia, pada akhirnya telah menjadi sebuah realitas yang tidak dapat terelakkan.

Pasca kemerdekaan, yakni setelah dikeluarkannya Maklumat Pemerintah No. X pada 16 Oktober 945 yang berisi pemberian kebebasan kepada seluruh masyarakat untuk membentuk partai politik guna menyalurkan aspirasi dan menyuarakan kepentingan kelompok - kelompok yang ada di dalam masyarakat. Tujuan dari Maklumat itu sendiri adalah sebagai persiapan masyarakat untuk menyongsong Pemilihan Umum (Pemilu) yang sayangnya tidak pernah terjadi karena terjadinya agresi militer I dari Belanda. Nanti setelah pengakuan kedaulatan Indonesia oleh Belanda setelah konferensi Meja bundar (KMB) 1949, akhirnya cita - cita untuk melaksanakan pemilu pertama kali tercapai dengan dilaksanakannya Pemilihan Umum pada tahun 1955. Pemilu itu sendiri, sebagaimana dicatat oleh Herbert Feith, diikuti tidak kurang dari 172 Partai Politik, organisasi dan Perseorangan. Dan masih tercatat sebagai pemilu paling demokratis didalam sejarah politik di Indonesia (Marijan, 2011).

Tabel I: Hasil pemilu 1955

\begin{tabular}{|l|r|c|c|}
\hline \multicolumn{1}{|c|}{ Partai Politik } & $\begin{array}{c}\text { Perolehan } \\
\text { Suara }\end{array}$ & Persentase & $\begin{array}{c}\text { Jumlah } \\
\text { kursi }\end{array}$ \\
\hline PNI & 8.434 .653 & $22,3 \%$ & 57 \\
\hline Masyumi & 7.903 .886 & $20,9 \%$ & 57 \\
\hline NU & 6.944 .141 & $18,4 \%$ & 45 \\
\hline PKI & 6.176 .914 & $16,4 \%$ & 39 \\
\hline PSII & 1.091 .160 & $2,9 \%$ & 8 \\
\hline Parkindo & 1.003 .325 & $2,6 \%$ & 8 \\
\hline Partai Katolik & 770.740 & $2,0 \%$ & 6 \\
\hline PSI & 753.191 & $2,0 \%$ & 5 \\
\hline IPKI & 541.306 & $1,4 \%$ & 4 \\
\hline PERTI & 483.014 & $1,3 \%$ & 4 \\
\hline MURBA & 199.588 & $0,5 \%$ & 2 \\
\hline LAIN - LAIN & 3.472381 & $9,3 \%$ & 22 \\
\hline
\end{tabular}

Sumber: Herbert Feith, The Indonesian Election 1955

Hasil Pemilihan Umum 1955 menghasilkan hanya empat partai politik yang meraih suara signifikan dengan memperoleh suara diatas $15 \%$ dan empat partai lagi yang 
memperoleh dukungan kurang berarti dengan memperoleh dukungan antara 2 sampai $3 \%$. Beberapa partai politik hanya hanya mendapatkan sokongan suara yang sangat minim, meskipun diantara mereka juga ada yang memperoleh kursi di parlemen. Partai politik peraih suara diatas $15 \%$ sekaligus mencerminkan kondisi sosial politik dimasa itu sebagai partai yang memilik basis ideologi yang kuat. PNI dengan dukungan kuat dari kaum Nasionalis, khususnya di daerah Jawa. Masyumi yang memperoleh dukungan dari pemilih Islam Modern (wilayah Jawa dan luar Jawa). NU mendapatkan suara dari kaum Islam Tradisional, terutama dari Jawa Timur dan Jawa Tengah. Sementara PKI memperoleh dukungan suara yang kuat dari para pendukungnya, baik di wilayah Jawa maupun dari luar wilayah Jawa (Feith, 1971).

Mengingat empat partai politik mendapatkan suara signifikan, memunculkan pertarungan kepentingan yang sangat seru dalam proses - proses di parlemen. Pertarungan itu selain berasal dari ikatan ideologi berbeda yang berakibat pada jatuh bangunnya kabinet. Juga ditambah adanya gangguan dari presiden Soekarno yang merasa terpinggirkan pada proses - proses politik saat itu. Akhirnya, demokrasi parlementer runtuh seiring Soekarno, atas dukungan militer memaklumatkan dekrit presiden untuk kembali ke UUD 1945. Setelah keruntuhan demokrasi parlementer dan Indonesia memasuki kegelapan bagi partai - partai politik dengan dibentuknya demokrasi terpimpin oleh Soekarno atas dukungan pihak militer dibawah pimpinan jendral Nasution. Sejarah kegelapan bagi partai - partai politik saat itu berakhir setelah demokrasi terpimpin runtuh dan naiknya Jenderal Soeharto sebagai penguasa baru pasca Gestapu tahun 1965, dan menyebut pemerintahannya sebagai Orde Baru. Tetapi, naiknya pemerintahan orde baru saat itu tidak memberikan ruang kebebasan lebih bagi partai - partai politik yang ada. Bahkan Masyumi sebagai partai politik terbesar ditahun 1955 bersama PNI tetap dilarang beraktivitas dan namanya tidak pernah dipulihkan. Ternyata, Orde baru tetap melanjutkan kebijakan lama dari demokrasi terpimpin Soekarno. Memang, pemilu pertama dimasa Orde Baru akhirnya jadi dilaksanakan tahun 1972, tetapi sudah merupakan rahasia umum bahwa sejak pemilu pertama dilaksanakan hingga kejatuhannya tahun 1998, pemilu - pemilu tersebut jauh dari anggapan demokratis. Bahkan dari segi kebebasan untuk berserikat, mengeluarkan pendapat dan berekspresi, Orde Baru lebih melakukan kebijakan pengurangan jumlah partai politik dengan memaksa partai - partai politik tersebut diluar GOLKAR melakukan fusi (penggabungan). Alhasil, sejak pemilu 1977 hingga pemilu 1997 partai politik yang ikut dalam pemilihan umum hanya dua partai politik yakni Partai Persatuan Pembangunan (PPP) dan Partai Demokrasi Indonesia (PDI), ditambah partai GOLKAR sebagai partai pemerintah. 


\section{Lanskap Partai politik Pasca Reformasi Pemilu 1999 - 2004}

Mari kita telusuri jejak partai politik disaat terbukanya kran demokratisasi pasca orde baru yang melahirkan sebuah euphoria dalam berdemokrasi. Alhasil bermunculannya banyak partai - partai politik baru. Mungkin kurang lebih dari 48 partai politik terbentuk untuk menyongsong pemilihan umum yang demokratis kedua di Indonesia yakni Pemilu tahun 1999 dimana 22 partai politik berhasil menempatkan wakilnya di dalam parlemen. Sepertinya sejarah telah terulang kembali, Pemilihan umum tahun 1999 juga menghasilkan pola yang serupa dengan Pemiliu legislatif tahun 1955. Jika Pemilu tahun 1955 ada empat partai politik peraih suara signifikan, maka di Pemilu tahun 1999 hanya menghasilkan dua partai politik yang mendapatkan perolehan suara sangat signifikan, yakni PDI Perjuangan dan GOLKAR Meski demikian, beberapa partai politik cukup mendapatkan suara diatas 5\%. Sehingga hasil Pemilu tahun 1999 menghasilkan lima partai besar, diantaranya adalah Partai Demokrasi Indonesia Perjuangan (PDIP), GOLKAR, Partai Kebangkitan Bangsa (PKB), Partai Persatuan Pembangunan (PPP) dan Partai Amanat Nasional (PAN). Sisanya, hanya mendapatkan perolehan suara kurang dari $2 \%$.

Tabel 2: Hasil Perhitungan Suara Sah Partai Politik Peserta Pemilihan Umum Legislatif 1999

\begin{tabular}{|l|l|r|c|}
\hline No. & \multicolumn{1}{|c|}{ Partai Politik } & $\begin{array}{c}\text { Perolehan } \\
\text { Suara }\end{array}$ & $\begin{array}{c}\text { Persentase } \\
\text { Suara }\end{array}$ \\
\hline 1. & PDI Perjuangan & 35.789 .017 & $33,7 \%$ \\
\hline 2. & GOLKAR & 23.714 .749 & $22,4 \%$ \\
\hline 3. & PPP & 11.329 .905 & $10.7 \%$ \\
\hline 4. & PKB & 13.336 .982 & $12,6 \%$ \\
\hline 5. & PAN & 7.528 .956 & $7,1 \%$ \\
\hline 6. & PBB & 2.049 .708 & $1,9 \%$ \\
\hline 7. & Partai Keadilan & 1.436 .565 & $1,4 \%$ \\
\hline 8. & PKP & 1.063 .810 & $1,0 \%$ \\
\hline 9. & PNU & 679.179 & $0,6 \%$ \\
\hline 10. & PDKB & 550.846 & $0,5 \%$ \\
\hline 11. & PDI & 655.048 & $0,6 \%$ \\
\hline 12. & PP & 590.995 & $0,6 \%$ \\
\hline 13. & PPIIM & 456.750 & $0,4 \%$ \\
\hline 14. & PDR & 427.875 & $0,4 \%$ \\
\hline 15. & PSII & 375.920 & $0,4 \%$ \\
\hline 16. & PNI Front Marhaenis & 365.176 & $0,4 \%$ \\
\hline 17. & PNI Massa Marhaen & 345.629 & $0,3 \%$ \\
\hline 18. & IPKI & 328.654 & $0,3 \%$ \\
\hline 19. & PKU & 300.064 & $0,3 \%$ \\
\hline 20. & PKD & 216.663 & $0,2 \%$ \\
\hline
\end{tabular}

Sumber: Diolah dari data KPU dan Badan Pusat Statistik 
Meski pemerintahan yang terbentuk pasca Pemilu 1999 bukanlah sistem parlementer sebagaimana hasil Pemilu 1955. Tetapi, pola koalisi antar partai politik tetap juga terjadi. Hasilnya, PDI Perjuangan sebagai partai peraih suara terbanyak tidak mampu merebut kursi kepersidenan akibat gagalnya membangun koalisi denan partai politk lainnya. Sebaliknya, meskipun dari partai menengah, PKB berhasil menempatkan kandidatnya KH Abdurrahman Wahid alias Gus Dur sebagai Presiden karena berhasil didukung oleh koalisi partai yang lebih besar. Meski berhasil terpilih sebagai presiden, Abdurrahman Wahid tidak mampu menjaga kepercayaan yang telah diberikan oleh partai - partai politik yang telah mendukungnya menjadi Presiden. Dimotori oleh orang yang sama, Amien Rais, akhirnya Gus Dur pun harus turun dari tahta kekuasaannya yakni kursi kepresidenan. Hal ini disebabkan banyak kebijakannya yang diambil dianggap fatal oleh partai - partai politik di parlemen, yang waktu itu kekuasaannya sudah sangat besar dibandingkan sebelumnya.

Tabel 3: Hasil Perhitungan Suara Sah Partai Politik Peserta Pemilihan Umum Legislatif 2004

\begin{tabular}{|l|r|c|}
\hline \multicolumn{1}{|c|}{ Partai politik } & \multicolumn{1}{c|}{$\begin{array}{c}\text { Perolehan } \\
\text { suara }\end{array}$} & $\begin{array}{c}\text { Persentase } \\
\text { suara }\end{array}$ \\
\hline GOLKAR & 24.480 .757 & $21.57 \%$ \\
\hline PDI PERJUANGAN & 21.026 .629 & $18.53 \%$ \\
\hline PKB & 11.989 .564 & $10.57 \%$ \\
\hline PPP & 9.248 .764 & $8.15 \%$ \\
\hline DEMOKRAT & 8.455 .225 & $7.45 \%$ \\
\hline PKS & 8.325 .020 & $7.34 \%$ \\
\hline PAN & 7.303 .324 & $6.44 \%$ \\
\hline PBB & 2.970 .487 & $2.62 \%$ \\
\hline PBR & 2.764 .998 & $2.44 \%$ \\
\hline PDS & 2.414 .254 & $2.13 \%$ \\
\hline PKPB & 2.399 .290 & $2.11 \%$ \\
\hline PKPI & 1.424 .240 & $1.26 \%$ \\
\hline PPDK & 1.313 .654 & $1.16 \%$ \\
\hline PNBK & 1.230 .450 & $1.08 \%$ \\
\hline Partai Marhaenis & 929.159 & $0.82 \%$ \\
\hline Partai Pelopor & 878.932 & $0.77 \%$ \\
\hline PPDI & 855.811 & $0.75 \%$ \\
\hline
\end{tabular}

Sumber: Diolah dari data KPU dan Badan Pusat Statistik

Fenomena pemilu legislatif di tahun 1955 dan 1999 kembali terulang di pemilu legislatif di tahun 2004. Pembentukan partai politik pada Pemilu tahun 2004 meski berkurang setengahnya dari 24 partai politik dari pemilu tahun 1999, tetapi partai politik yang ada jumlahnya tidak bisa dikatakan sedikit. Tetapi, pemilu tahun 2004 jumlah partai politik semestinya semakin berkurang. Apalagi dengan diterapkannya kebijakan Electoral Threshold (ET) sejak pemilu tahun 1999. Namun, pada pemilu 2004 partai politik baru seperti Demokrat, Partai Damai Sejahtera dan Partai Bintang Sejahtera mendapatkan suara yang dikonversi menjadi kursi diparlemen. Jika jumlah partai begitu 
banyak pada pemilu legislatif tahun 1955 dan 1999, hal itu bisa dimaklumi karena efek dari kebebasan berekspresi dan belum ada kebijakan penerapan ambang batas suara parlemen.

Menariknya adalah partai Demokrat sebagai partai baru pendatang baru di perpolitikan nasional mampu duduk meraup 8 juta suara serta sebagai peraih suara terbesar ke 5 yang menunjukkan bahwa partai politik baru bisa bersaing dengan partaipartai yang lama berada dalam parlemen. Masuknya partai Demokrat berimplikasi pada peta politik yang semakin menambah sengit tarik menarik kepentingan antar parpol di parlemen. Semestinya pada pemilu legislatif tahun 2004 jumlah partai politik semestinya semakin berkurang pada kenyataannya tidak. Apalagi dengan diterapkannya kebijakan electoral threshold yang terdigtum dalam Undang-Undang pemilu Nomor 3 Tahun 1999 menyatakan bahwa untuk dapat ikut serta pada pemilu selanjutnya parpol memiliki 2 persen jumlah kursi di DPR, 3 persen di DPRD provinsi, kabupaten dan kota di seluruh Indonesia. Namun, elit - elit parpol di parlemen bisa berkelit dari regulasi yang ada yakni dengan dibentuknya kebijakan baru dengan membentuk Undang undang baru No 12 Tahun 2003 yang menyatakan apabila partai politik tidak dapat melewati ambang electoral threshold maka partai politik bisa mengganti nama dan lambang untuk dapat ikut kembali di pemilu tahun berikutnya (Www.hukumonline.com, 2007). Saat itu, Partai Keadilan tidak bisa memenuhi electoral threshold maka untuk dapat kembali berkompetisi di pemilu legislative jalan yang dilakukan adalah dengan cara bermetamorfosis dengan mengganti nama menjadi Partai keadilan Sejahtera (PKS). Beberapa partai politik lainnya juga berhasil mengubah nama agar tetap dapat ikut pemilu, tetapi dari sekian banyak partai yang berhasil bermetamorfosis, hanya partai keadilan yang berhasil mendapatkan perolehan suara cukup signifikan dan bertahan dari pemilu ke pemilu.

\section{Sejarah Penerapan Parliamentary Treshold Pemilu Indonesia}

Menariknya memasuki rezim kebijakan Parliamentary Treshold pada pemilu tahun 2009 yang jauh lebih ketat, justru jumlah partai politik makin bertambah ketimbang pada pemilu tahun 2004. Jumlah keseluruhannya adalah 44 partai politik, 6 diantaranya adalah partai lokal Aceh. Menariknya pada pemilu legislatif 2009 saat penerapan parliamentary threshold yang tercantum dalam Undang - Undang Nomor 10 Tahun 2008 yang menyebutkan peserta pemilu legislatif harus memenuhi ambang batas perolehan suara sebesar 2,5 persen justru memunculkan partai - partai baru yang berhasil lolos ke parlemen. Terdapat 2 partai politik baru yang dianggap fenomenal yaitu partai HANURA dan GERINDRA. Bisa dikatakan kedua partai politik ini merupakan pecahan dari partai GOLKAR. Partai Hanura yang dipimpin Jendral Wiranto dan partai Gerindra dengan pentolannya Prabowo mampu menarik dukungan elektoral dengan menembus parliamentary threshold 2.5 persen dan berhasil masuk dalam parlemen juga membuat 
peta politik di parlemen semakin terfragmentasi. Justru yang menarik adalah Demokrat mampu menggerus suara elektoral sebesar 150 persen dari 7,45 persen pada pemilu legislatif 2004 menjadi 20,85 persen di pemilu legislatif 2009 ini membuat partai politik seperti PDI perjuangan dan Golkar harus kehilangan banyak dukungan elektoral. Kekuatan figur SBY selaku ketua umum menjadi magnet kuat yang berimplikasi pada besarnya suara elektoral yang didapatkan partai Demokrat di pemilu legislative 2009.

Pada pemilu 2014 aturan parliamentary threshold kembali digodok oleh Parlemen yang mengelurkan Undang - Undang Nomor 8 Tahun 2012, dengan ambang batas perolehan suara sebesar 3,5 persen. Agar partai politik baru untuk dapat berkompetisi dibentuk regulasi baru tentang syarat partai politik baru peserta pemilu legislatif tahun 2014 dengan syarat 30 persen perwakilan perempuan di kepengurusan Partai politik di tingkat pusat maupun daerah dengan jumlah anggota minimal 1000 orang serta mempunyai kantor kepengurusan di seluruh daerah di Indonesia. Hal ini tidak menjadi persoalan bagi munculnya partai-partai politik baru yang mana jumlah partai yang mendaftar untuk mengikuti pemilu legislatif sebanyak 46 partai politik namun yang lolos dari seleksi verifikasi administrasi dan faktual KPU berjumlah 12 partai politik. Menariknya dalam kontestasi pemilu legislative di tahun tersebut pada kenyataannya 10 partai politik berhasil lolos parliamentary threshold dan jumlahnya lebih banyak ketimbang pemilu legislative 2009 dengan jumlah parliamentary threshold yang berbeda. Selain itu, pada pemilu legislative saat itu partai NASDEM sebagai partai underdog mampu meraih dukungan elektoral yang membawanya masuk ke parlemen.

Sedangkan pada pemilu legislatif di tahun 2019 aturan parliamentary threshold kembali dibentuk Undang - Undang Pemilu Nomor 7 Tahun 2017 yang menetapkan 4 persen perolehan suara nasional. Hal ini juga tidak memutus bertumbuhnya partai politik dimana saat itu jumlah partai politik yang lolos verifikasi administrasi dan faktual pun bertambah berjumlah sebanyak 16 partai politik yang siap berkompetisi untuk merebut suara elektoral. Hasil pemilu legislatif di tahun 2019, partai politik yang mampu menembus ambang batas parlemen sebesar 9 partai politik yang meskipun jumlah partai berkurang dari pemilu legislatif ditahun 2014 sebesar 10 partai politik. Meskipun demikian, parliamentary threshold sebagai aturan main yang dibentuk untuk menekan masuknya partai politik baru serta untuk mengurangi jumlah partai politik di parlemen pada kenyataannya adalah sebuah angan - angan belaka. Realitasnya tampak jelas, aturan main dengan mengutak-atik besaran parliamentary threshold sebagai syarat agar partai politik dapat mengirim anggotanya ke parlemen tidak menyulutkan bertumbuhnya partai politik baru untuk hadir dan berkontestasi dalam arena elektoral di Indonesia. 
Tabel 4: Hasil Persentase Partai Politik Peserta Pemilihan Umum Legislatif 2009- 2019

\begin{tabular}{|l|l|l|l|l|}
\hline \multicolumn{1}{|c|}{ Partai Politik } & Pemilu 2004 & $\begin{array}{c}\text { Pemilu 2009 } \\
\text { PT 2,5\% }\end{array}$ & $\begin{array}{c}\text { Pemilu 2014 } \\
\text { PT 3,5\% }\end{array}$ & $\begin{array}{c}\text { Pemilu 2019 } \\
\text { PT 4\% }\end{array}$ \\
\hline PDI P & 18,53 & 14.03 & 18.95 & 19.33 \\
\hline GOLKAR & 21,58 & 14.45 & 14.75 & 12.31 \\
\hline PPP & 8.15 & 5.32 & 6.53 & 4.52 \\
\hline PKB & 10.57 & 4.94 & 9.04 & 9.69 \\
\hline PAN & 6.44 & 6.01 & 7.59 & 6.84 \\
\hline PKS & 7.34 & 7.88 & 6.79 & 8.21 \\
\hline DEMOKRAT & 7,45 & 20.85 & 10.9 & 7.77 \\
\hline HANURA & & 3.77 & 5.26 & 1.54 \\
\hline GERINDRA & & 4.46 & 12.57 & 11.81 \\
\hline NASDEM & & & 6.72 & 9.05 \\
\hline
\end{tabular}

Sumber: diolah dari data KPU \& Badan Pusat Statistik

Penjelasan sederhana yang mungkin bisa menguraikan mengapa di Indonesia masih bertumbuh partai - partai politik, termasuk partai hasil metamorphosis adalah karena partai politik masih mendapatkan pendanaan dari negara (public funding). Senada dengan Gary W. Cox dalam logika strategic entry kepunyaannya. Pandangannya bahwa munculnya partai - partai politik baru di sebuah Negara pada dasarnya merupakan keputusan elite politik untuk memasuki arena pemilihan sebagai kontestan baru. Terdapat tiga pertimbangan utama yang terdiri dari cost untuk memasuki arena, surplus yang dapat bilamana berada dalam kekuasaan (benefits of office) dan adanya kemungkinan untuk memperoleh dukungan dari partai pemilih (probably of receiving electoral support) (Marijan, 2006). Tesis Fox mendapatkan dukungan dari Margit tarvit yang meneliti di 22 negara maju. Menurutnya, kemunculan partai politik baru sangat berkaitan dengan biaya pendaftaran, terdapatnya dukungan keuangan, lenturnya lembaga - lembaga pemilihan misalnya biaya dalam memasuki arena pemilihan umum, tingkat korporatisme dalam keuntungan - keuntungan yang didapatkan di dalam kekuasaan, lama tidaknya tingkat demokrasi suatu negara, dan besarnya tanda - tangan yang dibutuhkan di dalam pembentukan partai baru (Marijan, 2006). Sehingga premis yang pas untuk melihat hal ini yakni terjadinya paradoksal elite partai politik yang berada di parlemen ketika membuat kebijakan penerapan electoral rules.

Tesis Fox bisa jadi terbukti, meski kenyataannya muaranya semua itu ada di parlemen yang dimana secara tiba - tiba menjelang Pemilu mengubah keputusan yang pernah dibuat. Atau setidaknya pengartikan lain apa yang pernah dimaksudkannya saat membuat regulasi dan aturan main pemilu. Salah satu yang paling disoroti adalah bahwa partai - partai politik yang tidak lolos electoral threshold maupun parliamentary threshold tetapi mendapatkan kursi di DPR langsung ikut pemilu dan tidak perlu lagi di verifikasi. Meski demikian, setidaknya ada harapan bahwa penyerdanaan jumlah partai politik bisa dilakukan yakni dengan diberlakukannya apa yang disebut parliamentary threshold (PT). Hasil tersebut dapat dibaca sebagaimana yang telah diduga bahwa 
jumlah pas untuk indonesia kisaran 7 hingga 8 partai politik saja, kalaupun juga dipaksa kisarannya sekitar 9 sampai 10 persen partai politik. Asumsi yang bisa dibangun adalah bahwa setiap pemilihan umum akan ada partai baru yang masuk di parlemen, tetapi di saat yang bersamaan akan ada pula partai politik kisaran 1 atau 2 partai eliminasi keluar dari parlemen.

\section{Praktik Parliamentary Threshold di Berbagai Negara: Sebuah Perbandingan}

Berkaitan dengan penerapan parliamentary threshold di Indonesia yang salah satu alasannya bahwa untuk penyederhanaan partai politik, tetapi tujuan akhirnya adalah agar terciptanya sebuah pemerintahan yang efektif di dalam sistem presidensial di Indonesia. Tetapi, fakta yang disodorkan oleh PERLUDEM (Perkumpulan Untuk Pemilu dan Demokrasi) menunjukkan bahwa ambang batas perwakilan (Threshold Representation) sangat bervariasi disetiap Negara (Supriyanto \& Mellaz, 2011).

Tabel 5. Parliamentary Threshold Nasional

\begin{tabular}{|l|c|c|c|}
\hline \multicolumn{1}{|c|}{ Negara } & $\begin{array}{c}\text { Tahun } \\
\text { Pemilu }\end{array}$ & $\begin{array}{c}\text { Jumlah } \\
\text { Kursi } \\
\text { Parlemen }\end{array}$ & $\begin{array}{c}\text { Besaran } \\
\text { PT }\end{array}$ \\
\hline Argentina & 2005 & 127 & 3 \\
\hline Brazil & 2006 & 513 & 3 \\
\hline Bulgaria & 2009 & 240 & 4 \\
\hline Kroasia & 2007 & 153 & 5 \\
\hline Republik Cheko & 2010 & 200 & 5 \\
\hline Yunani & 2009 & 300 & 3 \\
\hline Indonesia & 2019 & 575 & 4 \\
\hline Italia & 2008 & 617 & 4 \\
\hline Polandia & 2007 & 460 & 5 \\
\hline Korea Selatan & 2004 & 299 & 5 \\
\hline Turki & 2007 & 550 & 10 \\
\hline Jerman & 2017 & 598 & 5 \\
\hline
\end{tabular}

Sumber: diolah dari data Perludem

Misalnya pada pemilu legislative di Turki menetapkan parliamentary threshold sebesar 10 persen hingga tiada ada batas yang dikenakan diatas dan diluar jumlah suara yang diperlukan untuk memenangkan kursi di daerah pemilihan tertentu. Ambang batas hampir selalu diterapkan pada tingkat nasional untuk pemilihan umum legislatif tetapi tidak selalu dikaitkan dengan tingkat efektivitas pemerintahan (Reynolds \& Mellaz, 2011). Semangat penyederhanaan partai politik yang dilakukan oleh politik partai di parlemen tidak lepas dari apa yang penulis labeli dengan "Sindrom Mainwaring" Ashford (1993), yang melihat jumlah partai politik sebagai sumber masalah ketidakstabilan dan tidak efektifnya pemerintahan. Mainwaring menunjukkan dari seluruh demokrasi di dunia hanya Chile yang mampu mengawinkan secara stabil sistem sistem presidensial dengan sistem multipartai. Menurutnya, pengabungan sistem presidensial dengan 
sistem multipartai berpotensi menyebabkan deadlock dan terjadi instabilitas pemerintah (J. A. Chiebub, 2007).

Pendekatan dan pemikiran yang begitu deterministik tersebut sesungguhnya telah diperbaiki oleh J. A. Chiebub (2007) dalam studinya tentang persidensialisme dan kepartaian. Sunny Tanuwidjaja menyitir padangan Chiebub menunjukkan bahwa hubungan antara sistem pemerintahan dan sistem kepartaian tidak sesederhana yang disebutkan oleh Mainwaring. Ketika faktor seperti umur dari demokrasi atau pendapatan perkapita dimasukkan dalam perhitungan dan analisis, maka koalisi dalam menyimpulkan bahwa resiko instabilitas suatu pemerintahan baik dalam model sistem presidensial maupun sistem parlementer tidak dipengaruhi oleh apakah pemerintah tersebut itu satu, dua atau multipartai didalamnya (Tanuwidjaja, 2008). Hal ini diperkuat lagi oleh penelitian Chao (1987) dibanyak negara, dalam penelitian kedua sarjana ini, mereka menemukan bahwa sistem multipartai bukanlah menjadi faktor utama bagi ketidakstabilan politik dalam pemerintahan presidensial (Marijan, 2011).

Dapat dikatakan dari bahwa kita butuh penjelasan baru tekait dengan efektif tidaknya sebuah pemerintahan karena jumlah partai politik yang banyak. Bila kita merujuk pada apa yang ditawarkan dalam pemikiran Cheibub, bahwa tidak adanya disiplin partai, ikut menyumbang ketidak-efektif-an sebuah sistem presidensial (Jose Antonio Chiebub, 2007). Dari argumentasi Cheibub, hal tersebut telah mengamini apa yang telah bertahun - tahun lamanya yang katakan oleh Maurice Duverger, bahwasanya antara sistem Dwipartai dan sistem multipartai tidak jelas batasannya (demarkasi), ketika komposisi di parlemen demikian cair (Duverger, 1981). Selain itu, kita dapati pula temuan menarik bahwa parliementary threshold yang tinggi maupun rendah ternyata efeknya sepadan. Hal ini seperti pengalaman Albania, dalam penerapan ambang batas 2.5 persen atau sama dengan yang diterapkan di Indonesia pada pemilu 2009. Tetapi, jumlah partai yang menduduki parlemen tetap bisa terpangkas secara dramatis. Berdasarkan pemilu 28 Juli 2009 yang lalu di Albania, ada peserta pemilu terdiri atas 44 partai politik dan 1 independen. Jumlah ini juga hampir sama dengan peserta pemilu di Indonesia pada tahun 2009, yaitu 44 partai politik yakni 38 Partai Nasional 6 partai lokal.

Albania, hanya 6 partai yang berhasil meraih kursi di parlemen. Atau relatif sepadan dengan efek angka ambang batas besar di Jerman dan di turki. Adapun 6 partai tersebut adalah partai demokratik Albania (68 kursi), partai sosialis Albania (65 kursi), Gerakan Sosialis Integrasi (4 kursi), partai persatuan untuk HAM (1 kursi) partai republic dan partai keadilan dan integrasi (1 kursi). Keenam partai ini pun bergabung dalam tiga koalisi sehingga peta parlemen lebih sederhana yaitu Aliansi untuk perubahan (70 kursi), unifikasi untuk perubahan (66 kursi) dan aliansi Sosialis (4 kursi). Tetapi, jumlah partai yang mengerucut di Parlemen Albania terjadi setelah beberapa kali pemilu. Pada pemilu tahun 2005, jumlah partai yang berhasil lolos ke parlemen masih berjumlah 14 partai dan berkurang menjadi 8 partai pemilu tahun 2001. Bahkan, tanpa ambang batas pun, 
jumlah partai di parlemen tetap sederhana seperti yang terjadi di Spanyol, pernah menerapkan angka 3 persen. Tapi, pada pemilu 9 Maret 2008 tidak lagi ditetapkan. Meskipun demikian, jumlah partai yang meriah 350 kursi majelis rendah tetap tidak banyak yaitu 10 partai. Padahal pemilu diikuti oleh 84 partai/koalisi (Republik.co, 2011). Pemilu di Jerman juga mencatat sejak penerapan PT 5\% pada tahun 2005 terdapat 31 partai politik yang meloloskan 6 partai politik di parlemen, pemilu 2009 diikuti 28 partai politik lolos 6 partai politik, 39 partai politik meloloskan 5 partai politik di parlemen di tahun 2013 dan pemilu 2017 diikuti 42 partai politik meloloskan 7 partai politik di parlemen (Bundestag, 2020; Septian, 2019).

Ambang batas merupakan salah satu unsur dalam sistem multipartai dan sistem pemilihan perwakilan berimbang yang menetapkan bahwa suatu partai politik baru dapat menempatkan wakilnya di parlemen jika partai politik tersebut berhasil memperoleh persentase tertentu dari total suara nasional. Ini merupakan mekanisme untuk menghindari membanjirnya partai - partai sempalan (sprinter parties) ke dalam parlemen. Seperti tampak dari pengalaman berbagai negara persentase minimal ini berbeda - beda dari satu negara ke negara lain. Israel menetapkan kuota 1 persen, Denmark dan Norwegia 2 persen, Swedia 4 persen dan Jerman 5 persen. Menariknya Jerman dan Swedia Green Party atau partai hijau sebagai partai baru yang membawa isu lingkungan hidup dan disiplin yang ketat mampu merintangi dan masuk dalam parlemen dengan memperoleh suara diatas 6 persen di Swedia (Amal, 1996). Konteks Indonesia, meskipun di pemilu legislative 2019 muncul beberapa partai politik baru seperti PSI, partai Perindo, dan Partai Berkarya namun tidak mampu bersaing merebut suara elektoral untuk menembus parliamentary threshold. Dari hasil survey dua lembaga yakni Populi Center \& Median menjelaskan bahwa partai politik baru tidak dapat bersaing disebabkan lemahnya figur - figur partai politik baru kalah bersaing dengan partai mapan dan ideologi partai yang serupa dengan partai politik yang telah mapan (Renaldi, 2019).

\section{Membaca Kemungkinan Peta elektoral 2024}

Namun bagaimana dengan peta elektoral di tahun 2024? Pertanyaan ini begitu penting untuk mengukur apakah partai - partai politik yang berkompetisi mampu menembus parliamentary threshold. Walaupun kontestasi pemilu legislatif tahun 2024 masih jauh, namun elite - elite partai politik di parlemen siap mendesain ulang UU Nomor 17 Tahun 2017 tentang besaran PT yang akan berlaku di pemilu nantinya. Saat ini konsolidasi antar partai politik kerap dilakukan untuk mendiskusikan pengaturan PT pemilu 2024. Pertemuan Golkar dan Nasdem juga memberikan pendapat bahwa ada kesepakatan besaran berada di angka 7\% (okezone.com, 2020). Sementara partai pemegang kursi terbanyak di parlemen PDI Perjuangan juga mengusulkan besaran PT pada angka 5\% (Beritasatu.com, 2020). Sedangkan partai - partai kecil baik yang berada dalam parlemen maupun diluar parlemen menolak keras kenaikan PT pada pemilu 2024 
(Mujani, 2020). Namun beberapa lembaga survey telah melakukan survey terkait kontestasi politik pada pemilu 2024. Hasil data survey Charta Politika tentang elektabilitas partai politik yang dilakukan Juli 2020 menunjukkan beberapa catatan yang menarik (Politika, 2020). Hal serupa dari hasil survey Y- Publica merilis Peta Elektoral 2024 yang menunjukkan elektabilitas partai PDI Perjuangan, Gerindra dan Golkar masih diatas partai politik lainnya (Paat, 2020) .

\section{Grafik 1. Peta Elektoral 2024}

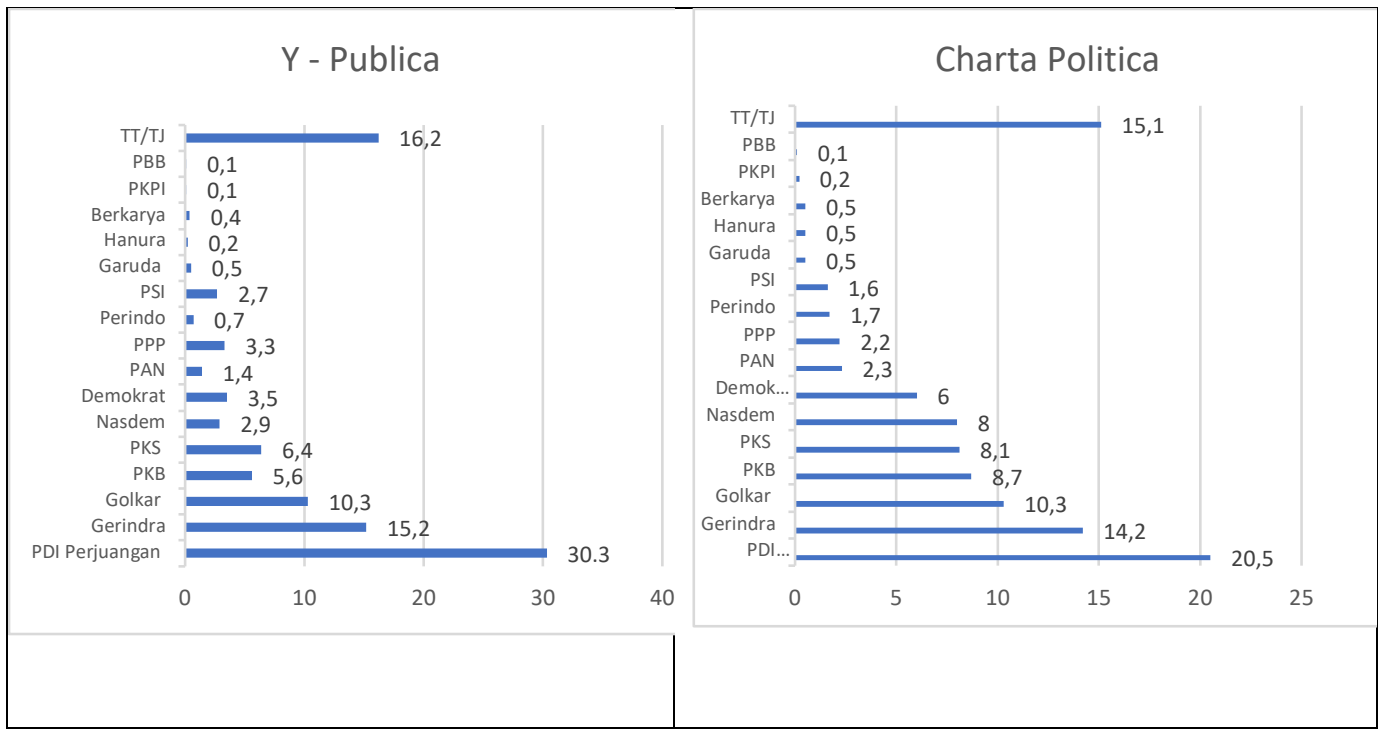

Sumber: diolah dari charta Politik \& Y-Publica

Apabila bersandar pada data survey Charta Politica, jika dianalisis maka bisa jadi kisaran 6 partai politik memiliki tingkat keterpilihan dengan kisaran $8-20 \%$ dukungan elektoral. Meskipun jumlah persentase yang tidak menjawab begitu besar sekitar $15 \%$. Sementara survey $Y$ - Publica menerangkan hal yang berbeda dimana hasil survey mengindikasi hanya 3 partai politik memiliki dukungan elektoral yang besar yakni PDI Perjuangan, Gerindra dan Golkar dengan jumlah persentase tidak menjawab sebesar 16.2\%. Kedua data pembanding ini bisa menjadi cerminan peta elektoral di pemilu 2024 apabila diukur dengan besaran PT pada angka 7\% boleh jadi jumlah partai politik yang lolos di pemilu 2024 kisaran 7 sampai 8 partai politik saja. Artinya parliamentary threshold sebagai aturan formal sebagai regulasi perbaikan sistem politik dan mutu demokrasi pada kenyataannya tidak dapat menyederhanakan sistem multipartai di parlemen.

\section{Penutup}

Penerapan parliamentary threshold pada politik elektoral tahun 2024 melulu menjadi perdebatan antara elite - elite partai politik di parlemen. Diskursus ini kemudian menggeliat diruang akademik, peneliti dan pemerhati pemilu dan demokrasi di Indonesia. Pada praktiknya, sejak pasca kemerdekaan hingga kini, penerapan parliamentary threshold tidak memberikan dampak besar terhadap penyederhanaan 
partai politik di parlemen. Justru multipartai menjadi sebuah keniscayaan yang mutlak harus diterima yang pandang sebagai sebuah kenormalan di era pemilu dan demokrasi Indonesia. Realitasnya pemberlakuan parliamentary threshold sebagai legal policy sejak 2009 hingga 2019 tidak mampu mengurangi jumlah partai politik di parlemen. Artinya kita harus menghilangkan pandangan bahwa penerapan parliamentary threshold menjadi cara jitu untuk menyederhanakan partai politik. Di aspek lain, penerapan tersebut juga tidak dapat memutus bertumbuhnya partai politik di Indonesia. Sejarah pemilu telah mencatat bahwa partai politik akan terus bertumbuh seiring berkembangnya demokrasi di Indonesia.

\section{Ucapan Terima Kasih}

Para penulis menyampaikan terima kasih yang sebesar-besarnya kepada yang terhormat Risal Suaib selaku guru dan sahabat yang selalu memberikan waktunya untuk berdiskusi dan bertukar pikiran.

\section{Pendanaan}

Penulis tidak menerima bantuan pembiayaan untuk penelitian, kepenulisan (authorship), dan publikasi dari pihak manapun.

\section{Daftar Pustaka}

Amal, I. (1996). Teori-Teori Mutakhir Partai Politik. Yogyakarta: Tiara Wacana Yogya. Aminah, S., Zia, H., Afita, C. O. Y., \& Sitorus, Y. (2020). Pengaturan Ambang Batas Perolehan Suara (Parliementary Threshold) Dalam Pemilu. Datin Law Jurnal, 4(3), 538-546.

Ashford, D. E. (1993). Localism and Centralism in Europe: The Political and Legal Bases of Local Self-Government. By Edward C. Page. New York: Oxford University Press, 1992. 186p. \$52.00. American Political Science Review, 87(2), 531-532.

Beritasatu.com. (2020). Mayoritas Fraksi Dukung Usulan Kenaikan Parliamentary Treshold, pp. 1-5.

Bundestag, G. (2020). Election to the 19 th German Bundestag, (October 2017), 1-2.

Chao, C.-M. (1987). "One Country, Two Systems" A Theoretical Analysis. Asian Affairs: An American Review, 14(2), 107-124.

Chiebub, J. A. (2007). Presidentialism, parliamentarism, and democracy. Choice Reviews Online (Vol. 45). https://doi.org/10.5860/choice.45-1687

Chiebub, J. A. (2007). Presidentialism, Parliamentarism, and Democracy. Reviews Online, 45(03).

CNN Indonesia. (2020). Revisi UU Pemilu, Ada 3 Opsi Penentuan Nasib Partai di 2024. Retrieved from https://www.cnnindonesia.com/nasional/20200609140340-32511402/revisi-uu-pemilu-ada-3-opsi-penentuan-nasib-partai-di-2024

Duverger, M. (1981). Partai-Partai Politik dan Kelompok-Kelompok Penekan. Surakarta: 
Bina Aksara.

Feith, H. (1971). The Indonesian Election of 1955. New York: Modern Indonesia Project. Southeast Asia Program, Cornell University.

Hadi, I. G. A. A., \& Brata, D. L. (2020). Pengaruh Penentuan Parliamentary Threshold Dalam Pemilihan Umum Legislatif dan Sistem Presidensial di Indonesia. Kertha Patrika, 42(1), 34-51.

Marijan, K. (2006a). Demokratisasi di Daerah: Pelajaran dari Pilkada Secara Langsung. Diterbitkan bersama Pustaka Eureka [dan] PusDeHAM.

Marijan, K. (2006b). Partai Baru, Electoral Threshold, dan Masa Depan Sistem Multipartai. Jurnal Politika, 2.

Marijan, K. (2011). Sistem Politik Indonesia : Konsolidasi Demokrasi Pasca-Orde baru. Jakarta: Kencana Prenada Media Group.

Mujani, S. (2020). Mengamati Pengamat Pemilu. Jakarta: Tempo.

NIMD. (2006). Suatu Kerangka Kerja Pengembangan Partai Politik Yang Demokratis. Netherland.: The Netherlands Institute For Multiply Democracy.

okezone.com. (2020). Bertemu Golkar, Nasdem Usulkan Parliamentary Threshold Naik Jadi 7 Persen, pp. 5-9.

Paat, Y. (2020). Survei Peta Pemilu 2024: PDIP Unggul, Prabowo-Anies Kalahkan Parbowo-Puan. Retrieved from https://www.beritasatu.com/politik/605519/ survei-peta-pemilu-2024-pdip-unggul-prabowoanies-kalahkan-prabowopuan

Partono. (2008). Sistem multipartai, presidensial dan persoalan efektivitas pemerintah. Legislasi Indonesia, 5(1), 13-28.

Politika, C. (2020). Rilis Survei Nasional Charta Politika Evaluasi Kinerja Joko Widodo K.H. Ma'ruf Amin dan Peta Elektoral 2024. Retrieved from http://www.chartapolitika.com/rilis-survei-nasional-charta-politika-evaluasikinerja-joko-widodo-k-h-maruf-amin-dan-peta-elektoral-2024/

Prihatmoko, J. J. (2005). Pemilihan kepala daerah langsung: filosofi, sistem, dan problema penerapan di Indonesia. Kerja sama Pustaka Pelajar dengan Lembaga Penelitian, Pengembangan dan ....

Prihatmoko, J. J. (2008). Mendemokratiskan PEMILU. Yogyakarta: Pustaka Pelajar.

Renaldi, A. (2019). Melacak Penyebab Semua Partai Baru Nyungsep Dalam Pemilu 2019. Retrieved from https://www.vice.com/id/article/j5wq53/melacak-penyebabsemua-partai-baru-nyungsep-dalam-pemilu-2019

Republik.co. (2011). Pemilih Muda Tentukan Masa Depan Bangsa. Retrieved from https://www.republika.co.id/berita/nasional/politik/18/03/18/p5s9jc428-kpupemilih-muda-tentukan-masa-depan-bangsa

Reynolds, A., \& Mellaz, A. (2011). PEMILU Indonesia : Mendiskusikan Penguatan Sistem, 53-70.

Septian, I. F. (2019). (Effecting the Government System and Simplifying the Political Party System :, 1-28. 
Simanjuntak, R. A. (2020). Tiga Opsi Besaran Ambang Batas Parlemen di Pemilu 2024. Retrieved from https://nasional.sindonews.com/read/62330/12/tiga-opsi-besaran -ambang-batas-parlemen-di-pemilu-2024-1591600004

Supriyanto, D., \& Mellaz, A. (2011). Ambang Batas Perwakilan. Perludem. Retrieved from http://perludem.org/2012/02/09/ambang-batas-perwakilan-pengaruhparliamentary-threshold-terhadap-sistem-penyederhanaan-partai-danproporsionalitas-hasil-pemilu/

Tanuwidjaja, S. (2008). Multipartai dan presidensialisme di Indonesia. Analisis CSIS, 17. Wardhono, A., Indrawati, Y., \& Qoriah, C. G. (2012). Kajian Pemetaan dan Optimalisasi Potensi Pajak dalam Rangka Meningkatkan Pendapatan Asli Daerah (PAD) Di Kabupaten Jember. J@Ti Undip: Jurnal Teknik Industri, 7(2),69-76.

www.cnnindonesia.com. (2020). Partai Nonparlemen Tolak Ambang Batas 5 Persen. CNN Indonesia, pp. 1-7.

Www.hukumonline.com. (2007). Electoral Threshold Hanya Dikenal di Indonesia. Retrieved from https://www.hukumonline.com/berita/baca/hol17517/ielectoralthresholdi-hanya-dikenal-di-indonesia/

Yuda, H. A. R. (2010). Presidensialisme Setengah Hati: Dari Dilema ke Kompromi. Jakarta: Gramedia Pustaka Utama.

Zed, M. (2014). Metode Penelitian Kepustakaan. Jakarta: Yayasan Obor Indonesia.

Zuhri, S. (2018). Proses Politik dalam Pembentukan Regulasi Pemilu: Analisis Pertarungan Kekuasaan pada Pembentukan Undang-Undang Nomor 7 Tahun 2017 tentang Pemilu. Jurnal Wacana Politik, 3(2), 94-107.

\section{Tentang Penulis}

Aenal Fuad Adam adalah Dosen Jurusan IImu Administrasi Negara, Fakultas IImu Sosial dan Ilmu Politik, Universitas Musamus Merauke. Penulis memiliki area riset seputar tema Pemilu dan parlemen, kajian elite dan Politik Lokal, dan politik Identitas.

Nur Jalal adalah Dosen Jurusan IImu Administrasi Negara, Fakultas IImu Sosial dan IImu Politik, Universitas Musamus Merauke. Penulis memiliki area riset seputar tema Kebijakan Publik.

Wellem Levi Betaubun adalah Dosen Jurusan Ilmu Administrasi Negara, Fakultas Ilmu Sosial dan Ilmu Politik, Universitas Musamus Merauke. Penulis memiliki area riset seputar tema Kebijakan Publik. 